Volume 1, Issue 2, pages 179-188

\title{
Designing Independent Automatic Drinking Water Platforms at Sanata Dharma University
}

\author{
Muhammad Prayadi Sulistyanto*, Ervan Erry Pramesta \\ Politeknik Makatronika Sanata Dharma, Yogyakarta, Indonesia \\ *Corresponding Author: prayadi.sulistyanto@gmail.com
}

(Received 23-01-2019; Revised 31-10-2019; Accepted 04-11-2019)

\begin{abstract}
Environmental pollution is increasing every year. From 2011 to 2014, environmental pollution in the Special Region of Yogyakarta increased above $250 \%$. The effect of environmental pollution is the decreasing availability of clean water. Sanata Dharma University as an institution engaged in the field of education seeks to provide clean water where clean water is suitable for drinking, namely with RO (Reverse Osmosis) technology. Drinking water distribution has run well in Sanata Dharma University, but it lacks hygiene. In this study, researchers Designing Independent Automatic Drinking Water Platforms that could distribute clean water ready to drink for students with a certain dose. The result of this study is that an independent automatic drinking water platform can provide $200 \mathrm{cc}$ of clean water ready for drinking in 9 seconds each time a user (student) uses this tool.
\end{abstract}

Keywords: RO, drinking water platform, automatic water 


\section{International Journal of Applied Sciences and Smart Technologies}

Volume 1, Issue 2, pages 179-188

p-ISSN 2655-8564, e-ISSN 2685-9432

\section{Introduction}

The level of environmental pollution in the Special Region of Yogyakarta, increased above 250 percent over the period of 2011 to 2014. The most common pollution in 2014 was air pollution, which occurred in 415 villages, while water pollution occurred in 44 villages and soil pollution occurs in 4 villages [1]. Environmental pollution is increasing every year, it will be inversely proportional to the need for clean water which continues to increase, so that it is obeyed by PT AQUA to open clean water plants, namely in the area of Klaten. Coinciding with World Water Day, the Klaten AQUA Factory held the inauguration of Embung Tirtamulya located in Pucang, Tegalmulyo Village, Kemalang District, Klaten to support water availability in a number of villages on the slopes of Merapi [2].

Various types of research related to efforts to reduce environmental pollution such as those conducted by Novita Sekarwati who conducted a study to reduce phosphate levels in laundry waste in the Tambakbayan, Catur tunggal, Depok, Sleman, Yogyakarta [3]. Another researcher, Oki Oktami Yuda, also conducted a study to suppress environmental pollution by controlling the pollution of hotel wastewater in the city of Yogyakarta in 2017 [4].

Sanata Dharma University, Yogyakarta, Indonesia as an institution engaged in the field of Education also strives to provide clean water where clean water is suitable for drinking, namely with RO technology. Drinking water distribution has run well in Sanata Dharma University, but it lacks hygiene in the supply of drinking water that is ready for consumption. So it takes a tool that can remove water cleanly, higinies and is able to remove water with the right dose and automatically.

This paper is written in the following structure. Part 2 describes the design of the tool. The method (steps) for making the tool will be described in Section 3. The results of the research and discussion are written in Section 4. This paper concludes with some conclusions. 


\section{International Journal of Applied Sciences and Smart Technologies}

Volume 1, Issue 2, pages 179-188

p-ISSN 2655-8564, e-ISSN 2685-9432

\section{Design}

The components used are a $B J 300-D D T-P$ sensor, a 12 Volt in out $1 / 2$ "Solenoid Valve, a $12 \mathrm{~V}$ Switch Adjustable Timer Switch Relay, and a $5-$ foot $12 \mathrm{~V}$ Relay. $B J 300-D D T-P$ sensor is a sensor used to detect the presence of objects in front of it with a maximum detection distance of $300 \mathrm{~mm}$ with the output type of this sensor being PNP [5]. Timer Switch Relay Adjustable $12 \mathrm{~V}$ module is a tool to set the lag time to turn on / off the equipment with a time lag of $0-10$ seconds. If you want a longer pause, you can replace the larger elco $(\mathrm{C} 1)$. Can be applied to alarms, time lags on/off lights and others according to creativity [6]. In this study, the electrical circuit used is as follows in Figure 1.

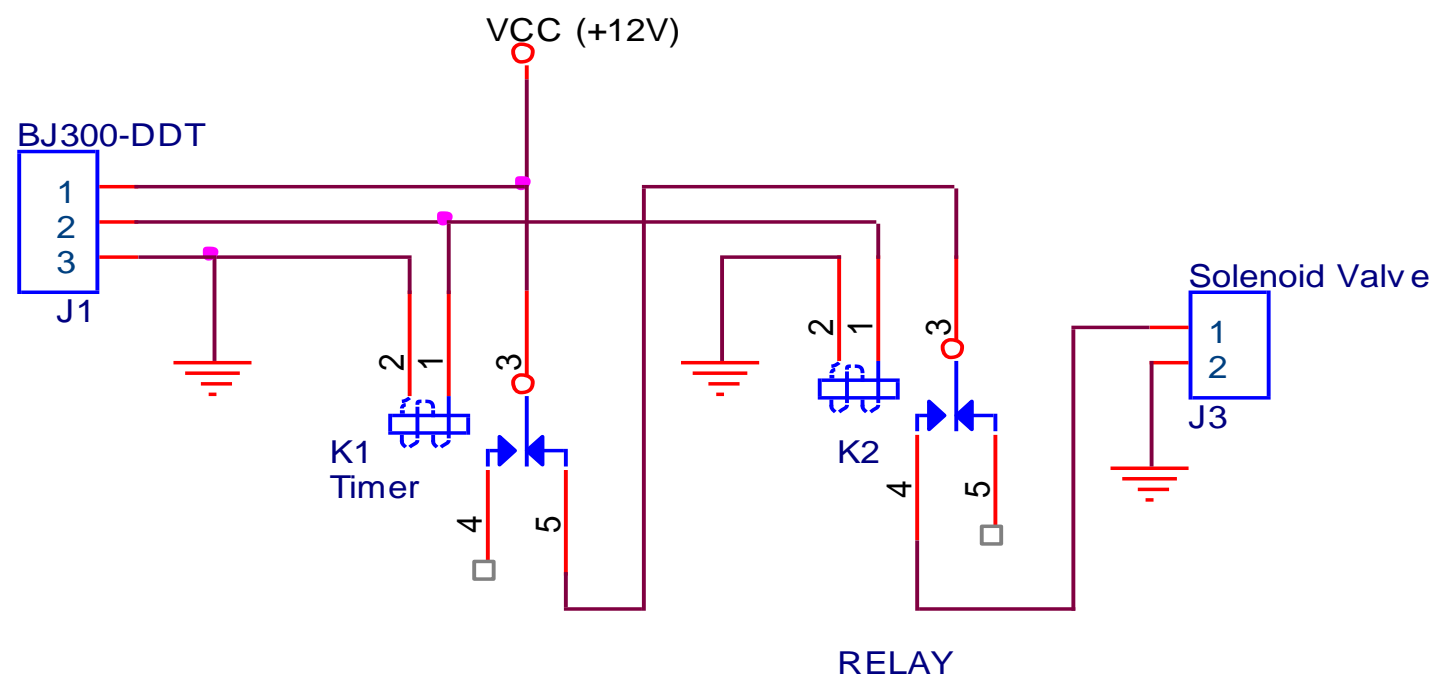

Figure 1. Electric Independent Automatic Drinking Water Platform

In Figure 1 the circuit used is quite simple, using only 5 components which are arranged in such a way that they can produce results according to the purpose of this study. The essence of the automated automated platform is the control of the opening of the faucet (solenoid valve) so that RO water can be distributed with a certain dose. The workings of the independent automatic drinking water platform system are as follows:

a. Users (students) take a glass that has been provided, then bring it to the RO head and the presence of the hand will automatically be detected by the sensor $B J 300-D D T$. 


\section{International Journal of Applied Sciences and Smart Technologies}

Volume 1, Issue 2, pages 179-188

p-ISSN 2655-8564, e-ISSN 2685-9432

b. The active sensor will activate the timer, and simultaneously activate the solenoid valve and because the solenoid valve is active, $\mathrm{RO}$ water will flow into the glass.

c. The active timer will count at a certain time, and if the specified time has been reached, the solenoid will die and the RO water will stop flowing.

d. RO water will still stop flowing even though the hand still reads the BJ300DDT sensor.

e. RO water will also stop flowing when the hand is not read by the $B J 300-D D T$ sensor even though the timer has reached the specified time.

Independent automatic drinking water platform is designed so that the users feel aesthetically comfortable. Figure 2 shows a design drawing of 3 dimensions of independent automatic drinking water platform and Figure 3 shows the dimensions of the tools and parts of an independent automatic drinking water platform.

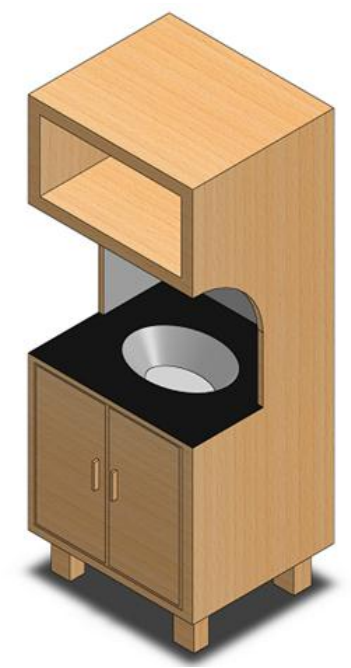

Figure 2. Design of an Independent Automatic Drinking Water Platform 


\section{International Journal of Applied Sciences and Smart Technologies}

Volume 1, Issue 2, pages 179-188

p-ISSN 2655-8564, e-ISSN 2685-9432
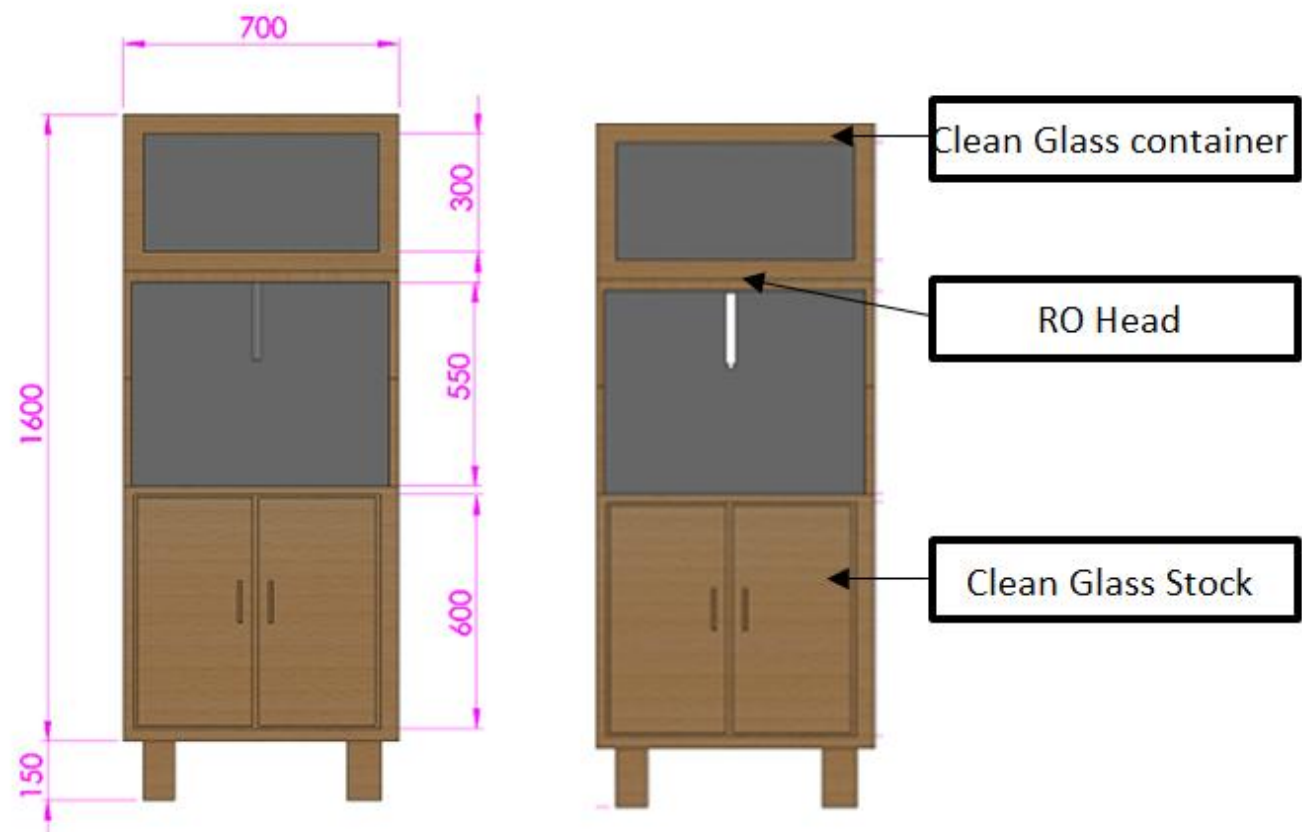

Figure 3. Dimensions and parts of the Independent Automatic Drinking Water Platform

The independent automatic drinking water platform designed has been equipped with a clean glass container that is ready to use which is above the RO head, making it easier for users to take advantage of this RO drinking water service. This tool is also equipped with a lower cupboard that can be used to store clean glass stock.

\section{Method}

The course of the research on the Design of an Independent Automatic Drinking Water Platform of Sanata Dharma University is:

a. Literature Review

Literature review is a study related to previous research and collects references $B J 300-D D T-P$, Solenoid Electric Water Valve $12 v N c$ In Out $1 / 2$ "Electric Faucet, New DC 12V. Pull Delay Timer Switch Relay Adjustable Module and material related to this research.

b. Making hardware

Making hardware starts from the design of placement of adapters, valves and sensors so as to facilitate maintenance. 


\section{International Journal of Applied Sciences and Smart Technologies}

Volume 1, Issue 2, pages 179-188

p-ISSN 2655-8564, e-ISSN 2685-9432

c. Data collection

Data retrieval is done by doing a timer test on the amount of RO water that comes out so that later can be determined the right time to produce the volume of $\mathrm{RO}$ water as expected.

d. Conclusion

Conclusions are the final results that refer to the research objectives.

\section{Results and Discussion}

The results of the implementation of the design an independent drinking water platform are shown in Figure 4. Installation of the sensor under the spot where the glass is clean and the direction of the reading is directed to the end of the RO head so that the sensor can detect the glass at the end of the RO head.
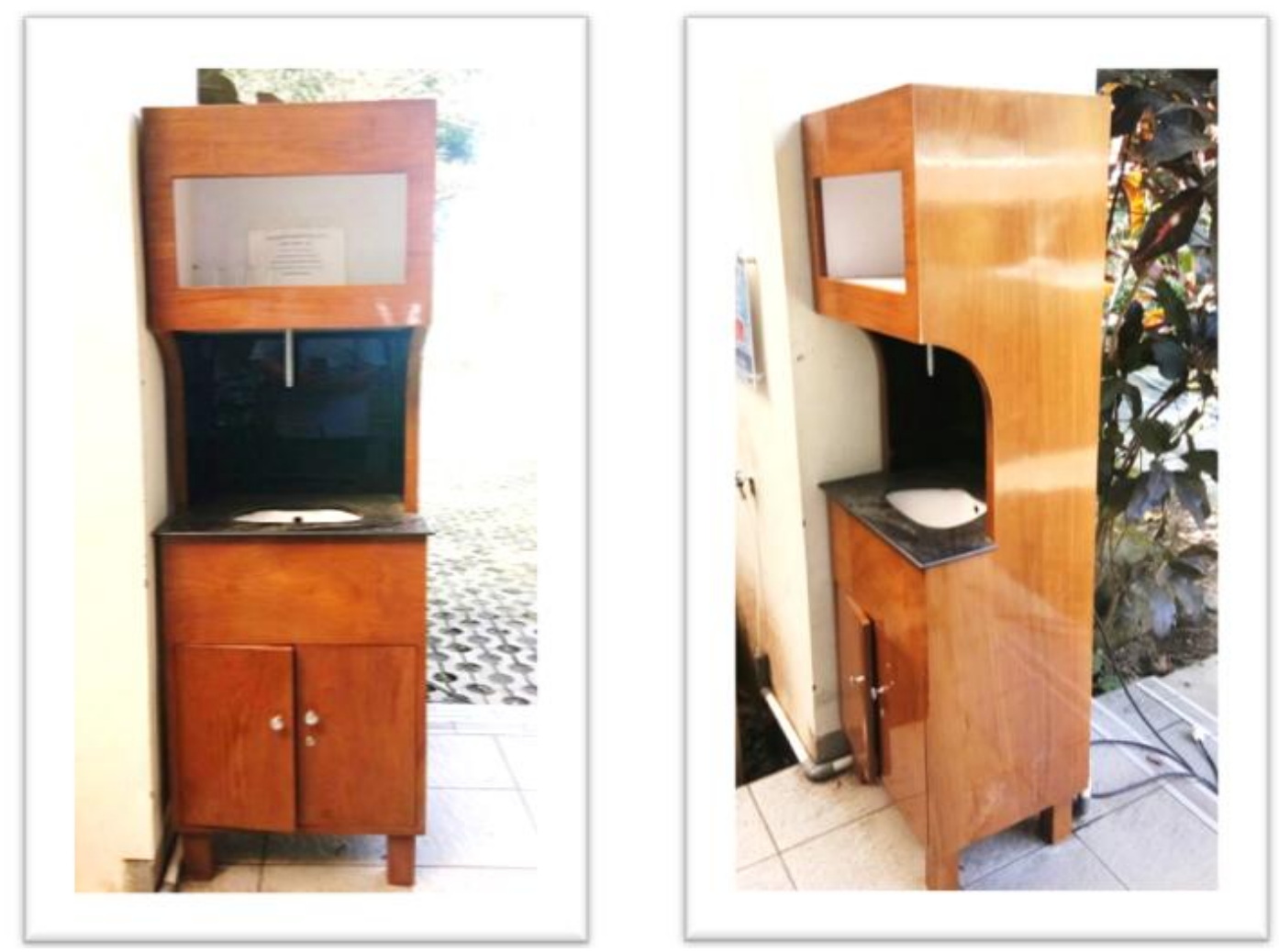

Figure 4. Independent Automatic Drinking Water Platform of Sanata Dharma University at Campus III Paingan, Maguwoharjo, Depok, Sleman, Yogyakarta, Indonesia 


\section{International Journal of Applied Sciences and Smart Technologies}

Volume 1, Issue 2, pages 179-188

p-ISSN 2655-8564, e-ISSN 2685-9432

Testing the system of independent automatic drinking water platforms is carried out with a source RO water discharge of $1.5 \mathrm{~L} / \mathrm{min}$. The test is done three times with the same timer value and monitors the RO water output that comes out.

Table 1. The first Test Result of the Independent Automatic Drinking Water Platform

\begin{tabular}{cc}
\hline Timer Value & Amount Of Water That Comes Out \\
\hline 1 second & - \\
2 second & $4 c c$ \\
3 second & $20 c c$ \\
4 second & $32 c c$ \\
5 second & $55 c c$ \\
6 second & $90 c c$ \\
7 second & $120 c c$ \\
8 second & $165 c c$ \\
9 second & $205 c c$ \\
10 second & $260 c c$ \\
\hline
\end{tabular}

Table 2. Test Result of both Independent Automatic Drinking Water Platforms

\begin{tabular}{cc}
\hline Timer Value & Amount Of Water That Comes Out \\
\hline 1 second & - \\
2 second & $5 c c$ \\
3 second & $15 c c$ \\
4 second & $28 c c$ \\
5 second & $60 c c$ \\
6 second & $95 c c$ \\
7 second & $130 c c$ \\
8 second & $160 c c$ \\
9 second & $190 c c$ \\
10 second & $250 c c$ \\
\hline
\end{tabular}

Table 3. Test Results Table of the Independent Automatic Drinking Water Platform

\begin{tabular}{cc}
\hline Timer Value & Amount Of Water That Comes Out \\
\hline 1 second & - \\
2 second & $5 c c$ \\
3 second & $15 c c$ \\
4 second & $30 c c$ \\
5 second & $60 c c$ \\
6 second & $90 c c$ \\
7 second & $130 c c$ \\
8 second & $170 c c$ \\
9 second & $200 c c$ \\
10 second & $250 c c$ \\
\hline
\end{tabular}




\section{International Journal of Applied Sciences and Smart Technologies}

Volume 1, Issue 2, pages 179-188

p-ISSN 2655-8564, e-ISSN 2685-9432

The results of the tests carried out on an independent automatic drinking water platform, when the sensor detects and the timer is set to 1 second, RO water has not had time to flow as shown in Tables 1-3. This is because there are 3 components ( 2 relays and 1 solenoid valve) which is active based on the principle of magnetic induction, so that when the timer setting is given 1 second, the solenoid valve is only active for a moment and RO water has not been able to flow.

The next time setting is a multiple of 1 second and the test results get varied results. Increasing the amount of RO water volume every second gets different results in each test. RO Water Discharge the output of an independent automatic drinking water platform in the first 3 seconds is $5.55 \mathrm{cc} /$ second. In the next second, the 4 to 6 seconds, the discharge of the RO water output from the independent automatic drinking water platform is $25 \mathrm{cc} /$ second. In the next second, which is 7 to 9 seconds, the RO water discharge from the independent automatic drinking water platform is $35.55 \mathrm{cc} /$ second.

The conclusion obtained from the research is that the RO water discharge from the independent automatic drinking water platform every second increases. The first 3 seconds to 9 seconds experienced a significant increase, up $30 \mathrm{cc} / \mathrm{second}$. So to get 200 cc results, it only takes 9 seconds as shown in Tables 1-3.

\section{Conclusion}

The conclusions that can be drawn from the study entitled designing independent automatic drinking water platforms can distribute clean water ready to drink students with a certain dose well. Independent automatic drinking water platform are arranged with a timer with an ON time of 9 seconds, so that when the user (student) needs clean drinking water, just take the glass provided, and when the hand is detected by the sensor, the water will come out during 9 seconds at a rate of $200 c c$. When the hand is not detected by the sensor, the water will automatically stop flowing even though the timer has not reached 9 seconds. 


\section{International Journal of Applied Sciences and Smart Technologies}

Volume 1, Issue 2, pages 179-188

p-ISSN 2655-8564, e-ISSN 2685-9432

\section{Acknowledgements}

This research was financially supported by Sanata Dharma Foundation. The author thanks the Director of Politeknik Makatronika Sanata Dharma and Innovation Center Politeknik Mekatronika Sanata Dharma for some discussions.

\section{References}

[1] L. Kertopati, Pencemaran Lingkungan di Yogyakarta Meningkat 250 Persen, https://www.cnnindonesia.com/nasional/20161023224728-20-167372/pencemaranlingkungan-di-yogyakarta-meningkat-250-persen (Accessed on 23-01-2019,15:03 WIB).

[2] https://aqua.co.id/pabrik-aqua-klaten-resmikan-embung-tirtamulya-untuk-dukungketersediaan-air-bersih, (Accessed on 23-01-2019,15:40).

[3] N. Sekarwati, "Penurunan Kadar Total Phosphat (Po4) pada Limbah Laundry dengan Metode Aerasi-Filtrasi Di Dusun Tambakbayan Catur Tunggal, Depok, Sleman, Yogyakarta”, Jurnal Kesehatan Masyarat, 11 (1), 2018.

[4] O. O. Yuda and E. P. Purnomo, "Implementasi Kebijakan Pengendalian Pencemaran Limbah Cair Hotel di Kota Yogyakarta Tahun 2017', Jurnal Administrasi Publik: Public Administration Journal, 8 (2), 2018.

[5] http://www.autonicsonline.com/product/product\&product_id=701 (Accessed on 2401-2019,18:00 WIB).

[6] New DC 12V Pull Delay Timer NE555 Switch Relay Adjustable Module, https://www.tokopedia.com/solarperfect/new-dc-12v-pull-delay-timer-ne555switch-relay-adjustable-module (Accessed on 23-01-2019,19:10 WIB). 
International Journal of Applied Sciences and Smart Technologies

Volume 1, Issue 2, pages 179-188

p-ISSN 2655-8564, e-ISSN 2685-9432

This page intentionally left blank 